\title{
THE AMBIGUOUS BEGINNINGS OF THE MODERN MISSION MOVEMENTS IN THE REFORMED CHURCH OF TRANSYLVANIA BETWEEN 1895 AND 1918
}

\author{
LEVENTE HORVÁTH* \\ Protestant Theological Institute
}

\begin{abstract}
This study looks at the ways how the Reformed Church encountered the new modern mission movement in Transylvania with the arrival of Dr. Béla Kenessey and Dr. István Kecskeméthy to the newly established Reformed Theological Seminary at Cluj in 1895. By the time being, some theologians expressed grave concerns about the dangers of theological liberalism to the Confessions. The paper argues that these young professors, touched by the mission movement and revival also sought to encompass those who had an evangelistic fervor to reach unbelievers and to serve those people in their personal and social needs. As a result, Christian Covenant was established in 1896, with official recognition in 1903 as the Christian Endeavor. It is hoped to unfold the major shifts regarding the attitudes to mission in the Reformed Church of Hungary and throw lights on ambiguous beginnings of mission movements.
\end{abstract}

KEY WORDS: Revival, Reformed Church of Hungary, liberal theology, mission movements

In this paper, I will look at the ways the church officialdom was encountering the new modern mission movement in Transylvania with the arrival of Dr. Béla Kenessey and Dr. István Kecskeméthy to the newly established Reformed Theological Seminary at Cluj in 1895. By the time being, some in the Reformed Church became alarmed by the encroachment of theological liberalism, mainly due to German influence (Kovács 2014: 51-55). These young professors touched by the mission movement and revival also sought to encompass those who had an evangelistic fervor to reach unbelievers and to serve those people in their personal and social needs. Thus, the Christian Covenant (Keresztyén Szövetség) was formed in 1896, with official recognition in 1903 as the Christian Endeavor (Kool 1995: 125).

I am aware that ' $(\mathrm{m})$ ission is never something self-evident, and nowhereneither in the practice of mission nor in even our best theological reflections

* LEVENTE HORVÁTH (PhD 2009, University of Wales) is an Associate Professor of Mission and Ecumenical Studies at Protestant Theological Institute, Cluj-Kolozsvár, Romania. Email: leventelhorvath@gmail.com. 
on mission, does it succeed in removing all confusions, misunderstandings, enigmas and temptations' (Bosch 1991: 9). However, at this point I want to use the challenging questions posed by Moreau, applying them to the Transylvanian situation. For example, does mission refer to the whole scope of God's salvific purpose in the world (as Sándor Tavaszy, the systematic professor of Kolozsvár Seminary in the period stressed), or, more narrowly, is it the God-given missionary task of the church as was believed by many others at the time? Again, if our focus is on the task of the church, is mission limited to one core component of the church's work or is it everything that the church does? Is it, in fact, possible to determine a focus or priority for mission, and, if so, what should that be? Was there any theological effort made to describe and define missions in accordance with the church's own creeds and doctrinal orientation, or were ideas about missions formulated simply as a response to pressing practical needs? [As Richard D. Love rightly observes: 'The relationship between conversion and mission is foundational to missiology, because the conversion of sinners is central to the fulfillment of the Great Commission.' See the entry: 'Conversion' in the EDWM, 231. The missiologist Timothy $\mathrm{K}$. Beougher is right when he states: 'It would not be an exaggeration to characterize the history of the modern mission movement as the story of revival. When genuine revival comes, believers are reawakened to their evangelistic and social obligations. Mission efforts are a natural fruit of revival.' See his article under the entry on 'Revival, Revivals' in the EDWM, 832. This latter understanding of mission was maintained in the period by Dr. Sándor Makkai, the influential theologian and bishop of the Transylvanian reformed church between 1926 and 1936.]

To be Hungarian in Romania was perceived in general by one's being born and baptized in the Hungarian Reformed Church of Transylvania, that being the historical denomination in majority, among Hungarians of Transylvania, before and after the 1918 Treaty of Trianon, resulting in the annexation of the region to Romania. This emphasis on ethnic identity hindered an interest in missions; consequently, the Church became defensive, inward looking and with no room for revivals, or for the 'home-mission movement', represented primarily by the rise and formation of the CE Associations, a movement channeling the revival spirit and missionary endeavor, into both Hungary and Transylvania at the second half of the 19th century. It took at least 30 years of struggle before Dr. Lajos Imre in the 1920s could 'churchinize' the home-mission movement and interest in missions could be domesticated. The shift could take place gradually, but distorted the concept of a missiologically consistent model, or even the concept of missions per se, as envisioned by Dr. István Kecskeméthy. This paper will focus heavily on a quick overview of the work and thinking of Kecskeméthy, an important figure playing a major role in the beginnings of what we call today, the 
Transylvanian mission movement. [Kool, following Ravasz, uses the term 'churchinize' to mean incorporation of the independent mission societies and their energies into the church. Bishop Dr. László Ravasz and later Dr. Sándor Makai tried to achieve this in Hungary; Professor Lajos Imre and then Dezső László tried the same in Transylvania (all four were Transylvanians, but first Ravasz in 1921, and then Makkai in 1936 moved to Hungary). To understand their effort, I quote Kool: 'To further the cause of reviving the official church Ravasz laid down a program of church renewal as an attempt to bridging the existing gap and to 'indigenize' the work done by the home mission societies. The antagonism between the official church and the societies originated in mutual suspicion. The home mission societies were sharp in their criticism of the churches, in which they saw the greatest hindrance in their work. Ravasz felt on the other hand that they often 'built the Kingdom of God in spite of the church'. In this situation he laid down his program to 'churchinize the Christians belonging to the societies by way of evangelizing the church' (az egyesületi keresztyénség egyháziasitását az egyház evangélizálása útján). Kool 1993: 306. An in-depth analysis of the two different paradigms of mission models, represented by two major missiologists, Dr. Lajos Imre and Dr. Kecskeméthy, I already proposed, compared and critically evaluated in my unpublished doctoral thesis, for details see there.]

Nevertheless, the whole church was influenced positively (the task of 'missionizing' the church was relatively achieved), although it happened slowly. Unfortunately, the Communist takeover of Romania after World War II made any legal and open mission activity of the Church impossible beginning with the late 1940s.

But the dichotomy between the mission movements of the sodalities and the missions work of the official church continued even after the eventual acceptance of these mission movements by the church officialdom, due to the influence of Dr. Lajos Imre; yet the tension lasted also. This situation remained unsolved, with occasional attempts to resolve it in a somewhat different way to that of the solution offered and practiced in Hungary. After World War II and in the transitional time of the Communist takeover, that situation solidified, a situation which served the compromise made by the official church with the Communist authorities. After the decisive years of 1948 and 1949, when all mission societies and associations were banned by government authorities, the church was supposed to take up the task of missions. But she could not, and would not do it properly, and all evangelization and mission work went underground in the 1950 s, continued only by a few ministers in great secrecy. [It was originally the ambitious program of the famous theological professor at Cluj, and later bishop at Budapest, Dr. László Ravasz, who stated as his aim to 'missionize the church and to churchinize missions'.] 
The general reformed view on missions, to which even the Transylvanian Reformed Church at that time was supposed to subscribe, always emphasized a Christ-centered and church-focused activity rather than the opposite, a Christfocused and church-centered activity. The latter could be a theological possibility, but certainly not a reformed theological possibility. For this comparison it is best to quote the contemporary theologians' reflections on the matter, as Imre declared: 'The church in mission is not gathering members to herself but to Christ; not into her own earthly organization, but into the temple of God's Kingdom' (Imre 1930: 117-128).

Similarly, Dr. Sándor Tavaszy, the leading dogmatician of the Transylvanian Reformed Church (TRC) in the period, emphasized:

(W)ithout the invisible church a community can be an excellent organization but cannot be a church. The invisible church is not just a life-condition, but also $a$ judgment on the church. Let us add that if it ceases to be a judgment, then the church is on its surest way to cease being the church [italics mine, LH] (Tavaszy 1929: 83).

Theologically, it is impossible to put the church in the center since the Reformers emphasized that Christ saves the sinner directly without the mediation of the Church. The Roman Catholic view would also claim Christ centeredness; yet because of the mediatory role of the church, practically still suggests a church centered view. Rather, it is a turning back to the Roman Catholic model and this must be noted because there were, and are, suggestions that the Transylvanian Reformed Church long after the Reformation and even today, still retains Roman Catholic elements in terms of church government. As stated above, it is possible to have a church-centered yet not a Christ-focused activity, but such a definition cannot be regarded as a mission model per se; it is a contradictio in adiecto. Such a model could be a 'cultural mission' but, by definition, not a Christian one. Similarly, is it possible to have a Christ-centered or, at least, a Christ-focused mission that is not also churchfocused as well? This is not a theological possibility according to reformed theology, although it might occur as a paradoxical possibility in the practice of some other denominations or groups. But such a model could not be called a strictly Biblical model, according to the Transylvanian theologians. By definition, this could not be called reformed, although it could be a mission model for groups, which minimalize the relevance of the church's visible appearance. These are groups, which overemphasize the invisible aspect of Christ's church on earth at the expense of the visible. I stated that, it is not a theological possibility according to reformed theology' neither as a personal view, nor as theological opinion on the matter, nor with a polemic tone against other denominations; but strictly based on a comparison between Hungarian Reformed Church reality and its official doctrinal standards, as these theologians claimed to believe it and as they interpreted it. 
We have to check throughout this paper whether these mission models 'were gathering members' to the church, to her 'own earthly organization' or 'to the temple of God's Kingdom' (Imre); whether 'a restriction of the sphere of the Kingdom' occurred (Victor); whether the TRC's leadership intended the church visible merely to be 'an excellent organization', and whether they allowed or refused the invisible church to be a judgment on the visible TRC (Tavaszy). These quotations above are enough to see the theological orientation and confessional stand. As a contrast to this, let us now turn to the practical reality in the Reformed Churches, as characterized by Victor: '(T)he Church seems to be something floating above the heads of individual believers. (...) The institutional aspect of the Church's life receives thereby an undue emphasis at the expense of its personalistic aspect. This tendency can be traced clearly with us to the influences of Roman Catholicism.' [Dr. János Victor, Answers to the Questionnaire concerning 'The Nature of the Church', 2-3. While Victor says: 'We would object to any too simple statement concerning the relationship of the 'Church' and the 'Kingdom'. To identify the two would mean on the one hand a restriction of the sphere of the Kingdom which extends beyond the limits of the Church [italics, LH] (the Kingdom involving also the exercise of the rule of God in Christ through the Church [underline by the author] over the life of the world) and on the other hand an obscuring of the eschatological aspect of the Kingdom. [italics, LH] A simple denial of the identification of 'Church' and 'Kingdom' however would militate against the fact that the 'Kingdom' in its most specific sense as Regnum Christi is a present reality in this world in the life of the Church.]

We need to compare Kecskeméthy's, Imre's, and László Ravasz's ideas concerning the missionary model that the church should follow, and to investigate how Reformed and biblical these concepts were. István Kecskeméthy (1864-1938) was born on 31 January 1864 in Paks, in the south west of Hungary. From 1880-1884 he studied at the Nagykőrös Reformed Gymnasium, where he was influenced spiritually and profoundly. According to the research of László Nagy (Nagy 1978: 139-140), among his teachers the greatest impact on his life was exercised first by Lajos Filó, who proclaimed as a theological principle that one must become a Christian first and only then can one become a theologian (Molnár 1996:67). With this emphasis he meant that, in contrast with the liberal theologians, faith must come before reasoning according to the Anselmian priority of theologizing embraced by all the Reformers.

Kecskeméthy became a student at the Budapest Reformed Theological Faculty in the autumn of 1884 and graduated in 1888. Between September 1888 and October 1890, he served as a secretary for Bishop Károly Szász of the Trans-Danubian District (which included Budapest), where together with Aladár Szabó and Béla Kenessey, he became a leading figure of the pietistic 
revivalist and mission movement embodied by the CE movement at that time. In 1895 he accepted the call of the Transylvanian Bishop Domokos Szász to the newly founded Cluj-Kolozsvár Seminary, being appointed by Bishop Szász together with four other professors.

Kecskeméthy was the professor of Old Testament studies until he suffered a stroke in 1936; he also headed the New Testament studies department for a long period as well. His teaching career in the Seminary amounts to more than 40 years; his teaching was as professional as it was confessional, with a conscious service of the cause of mission (Nagy 1995: 31). [Filó debated the ideas of rationalists in the church, such as Mór Ballagi, one of the most famous 'free thinkers' of the time, who questioned not only many reformed doctrines but who also attacked even the validity of the resurrection and the ascension into heaven of Christ. Filó responded in a book [see Filó L (1863) A keresztyén hit védelme a Krisztus feltámadása kérdésében (The Apology of Christian Faith Concerning Christ's Resurrection). Kecskemét. For the context it is important to read Kovács' book entitled Hitvédelem és Egyháziasság (Apologetics and Church-centeredness), 33-58. Molnár also suggests the importance of Filó whose influence is obvious in the work of Kecskeméthy. Although busy with many activities, he still found time to study at the philological faculty of the University of Budapest between 1888 and 1890, focusing on Latin Language and Literature, Greek Language and Literature, Hungarian Literature, German Literature, Indo-European Languages, Arabic Language and Literature, and Sanskrit. In May 1890 he received a doctorate in the comparative grammar of Eastern languages. He served as an associate minister in Buda between 1890 and 1894 and was so well-loved there that after leaving for Transylvania he was frequently invited back. In 1894 he married Irma Schodl; they had no children. The Cluj-Kolozsvár Francis Joseph University of Sciences of Kolozsvár (Ferenc József Tudományegyetem) was founded on 19 October 1872, an event which played a major role in the efforts of the bishop to bring the Seminary from Aiud-Nagyenyed to Cluj-Kolozsvár and join it as a Faculty of Divinity to the Royal University of Cluj/Kolozsvár. There was another professor, also not a Transylvanian, the above mentioned Kenessey, with the same evangelical beliefs and the same commitment for the revival of the church and for the cause of missions. Later they were both called 'the Evangelists to Transylvania, coming from the West'. Géza Nagy characterized him thus: 'To the new Institute he brought his thorough knowledge, his zealous and arduous missionary faith, his golden good spirits, and his typically Hungarian folk wisdom. In this spirit he would edit the edifying Kis Tükör magazine and other tracts. (...) His conscience was the prisoner of God's Word. (...) His interpretations of the Scriptures were practical, his preaching always revolved around the great facts of Christian life: the new birth, conversion etc. His rural origins and his practice as a pastor in a metropolis made 
him sensitive to the social movements. (...) He found an antidote to the materialistic movements of the masses in (the home) mission (movement) and in the protestant interpretation and practice of the universal priesthood of all believers.' ('Az új intézetbe magával hozza alapos tudását, buzgó misszionálásra hevitő hitét, aranyos kedélyét, tipikus magyar népi bölcsességét. E szellemben szerkeszti a Kis Tükör c. épitő lapot és traktátusait. (...) Az ő lelkiismerete pedig Isten Igéjének foglya. (...) Gyakorlati magyarázatai, igehirdetése azonban mindvégig a keresztyén élet nagy tényei, az újjászületés, megtérés, stb. körül forognak. Népi származása és világvárosi lelkészi mőködése a szociális mozgalmakra hivják fel figyelmét (...) A materialista tömegmozgalmak ellenszerét a belmisszióban, az egyetemes papság protestáns értelmezésében, megvalósitásában találja fel.')]

It was as early as 1896 that he organized the first Christian Unions or Associations ('Keresztyén Szövetség'), which later came together under the name of the CE or Bethany Movement, upon the latter's joining with the worldwide Christian Endeavour Movement. Kecskeméthy founded the Transylvanian branch and brought the Kis Tükör magazine from Budapest to Cluj-Kolozsvár. For decades, this was the famous organ of the missionary movement in Transylvania and Kecskeméthy remained its chief editor. Kis Tükör was the first family weekly magazine focused on the missionary and evangelization work of the church; it ceased publication in 1936, two years before his death. Between 1896 and 1907 Kecskeméthy planted a church on the outskirts of Kolozsvár, the Kolozsmonostor Reformed congregation, of which he was the first minister.

In 1900 he founded the Transylvanian Association of Evangelical Workers, the first Hungarian Christian non-ecclesiastical, non-profit organization accepted and registered by the Romanian government after the Romanian post-WWI takeover of Transylvania. In 1906, he became a member of the Hungarian parliament after publishing a study on 'The Impact of the Evangelical Spirit on the Life of the Nation'. Interestingly, the 'pietist' professor received a sharp criticism for this political activity from the more 'secular' or 'worldly oriented] Bishop Bartók the following year. [Kecskeméthy also edited a children's magazine, Napsugár from 1903-1907 and then became the chief editor of the official organ of the Református Lelkész Egyesület (Romanian Reformed Minister's Union), the Egyházi Figyelõ. In addition, he published many tracts, including a well-known series, Koszorú (Crown). From 1896 he was a member of the Magyar Protestáns Irodalmi Társaság (Hungarian Protestant Literature Society). The magazine was revived in 1993 by Koinónia Publishing in Cluj/Kolozsvár, Romania. In Hungarian: Evangéliumi Munkások Erdélyi Szövetsége or sometimes also called Evangéliumi CE Munkások Erdélyi Szövetsége. It functioned as an officially registered Romanian civil society that represented the CE separated from the sister CE in Hungary with the annexation 
of Transylvania by Romania. Just to illustrate his social impact on the society as a whole, it is worthwhile to mention also that he was a founder and chairman of the Gazdák és Tanitók Bankja (Bank of Landlords and Teachers), as well. Károli completed and published the whole Bible's translation into Hungarian in 1590 at Vizsoly (in the North-Eastern part of Hungary today).]

Between 1929 and 1934 he translated the whole Old Testament into Hungarian and then began again on yet another translation of the New Testament, until he was forcibly halted at Romans 1:9 by his stroke. Since the Hungarian Reformation and the 1590 translation of Gáspár Károli (Oliver 1991: 47-63), no one had ever managed to translate the entire Bible into Hungarian, as Kecskeméthy had done. Certainly, no one had ever done such a translation completely by themselves. He died on 10 May 1938 at the age of 74 having remained a leader of the CE Union all of his working life. [According to Oliver, '(t)wo of his (John Hus') Hungarian followers produced the first Hungarian translation of the Bible. His teachings helped to prepare the way for the later Hungarian Reformation.' However, only the Four Gospels in the München Codex (1466) were preserved. The Hungarian Reformation started as early as the 1520s. 'From the 1520s there were Lutheran preachers from Wittenberg active in Poland, Bohemia and Hungary.' Between 1522 and 1530 twenty Hungarian students matriculated in Wittemberg. The great champion of Reformation, Mátyás Dévai Bíró, lived in Luther's house before he returned to Hungary in 1531. But there was a turning to the Helvetic (Calvinist) reformation beginning with the Synod of Erdőd in Transylvania in 1545, with the Twelve Articles reflecting the distinctive Calvinist teaching on the Lord's Supper, 'but adding that in other matters they still agreed with the Lutheran Augsburg Confession' (Oliver). In 1559 there was a Synod held in Marosvásárhely, Transylvania, where again the Swiss line prevailed against Wittemberg. At last, in the 1567 Synod of Debrecen, they accepted the Second Helvetic Confession as the official standard of the Reformed Church of Hungary. Even Károli worked together with a whole team of ministers. Kecskeméthy's manuscript was almost destroyed under the Communists but finally, in 2002, his translation of the entire Bible was published by Koinónia Publishing in Kolozsvár, as a joint project with the Transylvanian District of the Reformed Church.]

János Molnár, in his essay on Kecskeméthy (Molnár 1996: 73), summarized his program and concept of mission by placing it in three major categories:

First, the preaching of the Word. The indispensable place for this is first and foremost the church but stepping out of the church building it can also occur both at home (the family) and through the (home) mission society as well.

Second, the practice of merciful love (or 'ministries of mercy'). This Diaconal work targeted children, the sick, prostitutes (founding the 'White Cross' 
society for fallen women), the homeless, and addicts (founding the Hungarian 'Blue Cross' society for the recovery of alcoholics and joining the worldwide temperance movement). Kecskeméthy also established the first Hungarian YMCA group in Transylvania among theological students.

Third, the practice of saving love. Spiritual counseling was regarded by him as the primary tool accompanied by regular home visits.

As early as November and December 1895, immediately after his arrival in Cluj-Kolozsvár, Kecskeméthy organized weekly 'reading evenings' at the Seminary on issues of faith, and this event was open to the public. This type of evangelization meeting, to my knowledge, had never been practiced before. Just a year later, a fierce attack was made on the representatives of the Home Mission Movement in the Protestáns Közlöny, charging them, and especially the young theological professor, with Nazarenism (Imre 1915: 49-53) and socialism. Kecskeméthy replied in the Protestáns Egyházi és Iskolai Lap with a phrase which later became famous and much quoted: 'He who fights against evangelism fights against his own church.' ['Nazarenism' here refers to the Church of the Nazarene, the evangelical denomination in the Wesleyan 'holiness' tradition which was Methodist in doctrine. In Hungary there was also established a Methodist church, but never in Transylvania. Kecskeméthy was labeled and attacked because evangelization was only practiced by these new groups and was unusual in the mainline churches. It is significant that Lajos Imre in his article: 'A munka irányító gondolatai' (The Guiding Principles of the Work) still considered the Methodist and Brethren Churches and the Salvation Army cults, even as late as 1915. In the feudalist society of Transylvania at the time, such an epitaph was almost like calling someone an anarchist or a communist, and in a church where lay leaders and patrons came from the noble classes, such a charge was injurious for Kecskeméthy.]

Another great missiologist of the period, the great-grandson of four reformed ministers, Dr. Lajos Imre (1888-1974) was born in Hódmezõvásárhely in eastern Hungary on 4 November 1888 but became a 'missionary of all in Transylvania'. He attended school in Hódmezõvásárhely and started his theological studies in Kolozsvár in September 1906. In his second year he wrote an important essay in Biblical Theology for Kecskeméthy, who noticed and expressed appreciation for the skills of the young student. In the same year, László Ravasz became his professor in Practical Theology and quickly recognized and encouraged Imre's abilities. While still a student, Imre committed himself to Practical Theology, especially to pastoral counseling and the catechism; Ravasz exercised a great influence on the younger man. In addition to his theological studies, Imre also attended courses in philosophy given by the famous neo-Kantian philosopher Károly Böhm (1846-1911), and courses in pedagogy given by the pedagogue István Schneller (1847-1939), both Protestant professors at the Ferenc József Tudományegyetem (Ferenc József 
University of Sciences). [Cf. 'He was regarded as such a missionary of the Transylvanian Reformed Church and as a commonly respected leader of whom everybody felt he was as his fellow-minister. He was active as the home mission commissioner of the Transylvanian District between 1924 and 1944. There could be found almost no congregation where his name was not known. Intrinsically he shared himself to full consummation in the ministry.' The coined word for the discipline was poimenics, based on the Greek for shepherd, poimen.]

In 1909, Imre encountered another man who was to influence his future ministry greatly. John Raleigh Mott (1865-1955) was an American (Primitive) Methodist missionary promoter (an Arminian in his theological orientation), converted during his student days who dedicated himself to work for worldevangelization and mission in general. He traveled to Hungary and in 1909 visited the Cluj-Kolozsvár Theological Seminary, accompanied by Dr. János Victor who translated his powerful messages. Victor also translated and published his book, The Decisive Hour of Christian Missions (A keresztyén missziók döntö órája). This visit had a lasting impact on both seminary professors and students, including Imre, and gave an impetus to youth work and missionary awareness, both of which had been virtually nonexistent before. Imre remembered Mott's visit with much satisfaction:

John Mott's visit in May of 1909 gave a new impulse to our lives and our work... Naturally, just like others, I too, was overwhelmed with his lecture. I listened to it with a secret satisfaction hoping that such a lecture, free of pietistic commonplaces, will convince our teachers and our fellow students of the importance and seriousness of the work that a few of us have already begun (Lajos 1999: 77).

It happened as Imre secretly hoped. One of his young teachers present there, Ravasz, wrote afterwards in the official magazine of the TRC, Református Szemle:

And he talked with such great power, such logical and rhetorical truth, such fascinating authority of his personality and conviction, that the hundreds of students of every kind who came to listen to the lecture listened to him with bated breath. I never met a man who could arouse my interest as well as he did. His speech was free of commonplaces, adornments and pathos. Every sentence was meant and simple. He was quite imposing in burning the truth he declared into the souls of his listeners. When he is writing he does not use a pen, but a chisel. What he says is valid for a lifetime... All his words reflect the seriousness of a last will. One cannot forget them even if one wants to... His speech lacks theoretical height and dogmatic depth. All his sentences are simple and natural as the truth itself, they deeply move the soul, because they are truth itself... He is the champion of the new Reformation of Protestantism, of the trend that has practical Christianity as its motto (Ravasz 1909: 249-252). 
Kenessey who was the Bishop of the Transylvanian District at the time of Mott's visit, had a similarly highly positive reaction in his Annual Report to the General Assembly:

John Mott is the powerful champion of practical Christianity, of the trend that urges and works on gaining souls for Protestantism and making them prisoners of Christ, i.e. Protestantism should form Christian religious characters (Kenessey 1909: 788-791).

[From 1888-1915 he was secretary of the YMCA and between 1888-1920 cofounder and president of the Student Volunteer Movement. He established the World Student Christian Federation in 1895 and in 1910 he became the chairman of the World Missionary Conference in Edinburgh. He was also the chairman of the International Missionary Council in 1921-1941 and led the Jerusalem Missionary Conference in 1928. In 1946 he received the Nobel Peace Prize and in 1948 he was named as the honorary president of the World Council of Churches, established in Amsterdam.]

It is interesting to observe that Mott was accepted by both the 'revivalistpietistic' and the 'traditionalist' sides in the TRC and that his influence went unchallenged despite his Arminian/non-Calvinist orientation and despite that he clearly believed that unity was more important than doctrine. The fact that Mott recognized and expressed the priority of experience over doctrine went unnoticed by, or at least drew no comments from, both Calvinist and liberal professors of the time. They, standing on the neo-Kantian ground proposed by their Hungarian mentor, the philosopher Károly Böhm, emphasized that the common religious experience of the church serves as a foundation to the ideal of the church. Similarly, the whole controversy around Mott's Student Voluntary Movement, was not an issue in the Hungarian context. The TRC never participated in these debates and never really questioned the doctrinal impact of his work. Perhaps this was due in part to the relative isolation of the TRC from the West. Ende observed that Mott's impact was important primarily for how the possibility of acceptance for the home mission movement became real:

Within the Theological Seminary the authority of Mott's personality gave the needed impulse to home mission, which the small group [i.e. the group around Kecskeméthy] with their previous initiatives for home mission had been unable to do so far (Ende 1990: 29).

Ende also noticed a change in Ravasz, who has been very 'critical of the youthevangelization before... Mott's lecture gained him over to the revivalism of the youth movement'. In my view this was the milestone for Ravasz, as he was 
gained for the mission movement and subsequently became the leader of the student mission work between 1908 and 1911 in Transylvania. Ravasz still favored the exclusive modality model against the sodalities in the mission movement, in apparent disagreement with Mott's position. Nevertheless, there is ample evidence to suggest (first in Ravasz's own articles written in praise of Mott in Református Szemle) that without the direct influence of Mott, Ravasz would probably not have been positive years later about the mission activity of the sodalities represented by Victor. For the same reason also, Ravasz may not have been so eager in 'churchinizing missions and missionizing the church', as worded in his declared program when he was Bishop of the Trans-Danubian District in Budapest.

The student mission work was organized under the name of Bethlen Gábor Kör (Bethlen Gábor Circle), and Imre became involved as an active member. This typically Transylvanian society became a sister-organization to the Magyar Evangéliumi Keresztyén Diákszövetség or MEKDSz (Hungarian Evangelical Christian Student Union) and Imre participated at the latter's conference in Balatonalmádi as a representative of the Transylvanian group. From this time, his realization of the need for evangelical revival and for practical Christianity began to grow gradually. Although at first he distanced himself from unhealthy 'pietism' (Imre 1999: 11, 75), he himself was later criticized for becoming a 'pietist', although he rejected the charge. Mott's influence and his slogan of 'the evangelization of the world in this generation' gained ground even in Transylvania during these years. ['This conference was very important to me. I did not sympathize either with the strict Pietists who believed in instant conversion and proved to be anti-cultural and narrow-minded, or with people like Tarnóczy who little valued the movement. I returned from the conference with the impression that these people talk about serious matters and about a deeper view of life, but it was impossible for me to accept their pietistic spirituality.' It is interesting how some CE Union members remembered the lasting influence of Mott and continued in the 1930s to follow his vision in their evangelizing strategy. For further study see, for example, some issues of Kis Tükör below. Mott's program was echoed in the call of the CE Union with the slogan: 'For the evangelization of Transylvania in this generation!' There were repeated callings for prayer and the organization of a geographical prayer chain of concentrated prayer weeks for the evangelization of Transylvania. See especially the emphasis on prayer at the November 1930 CE conference in Marosvásárhely, as we read in Kis Tükör 20(46): 181183 (dated 15 November 1930): 'Those present are invited for the battle with the weapons of the Word and Spirit, "For the evangelization of Transylvania in this generation".' (Az Ige és Lélek fegyvereivel való harcra hivuta föl a jelenlevőket 'Erdély evangélizálásáért ebben a nemzedékben!')] 


\section{Bibliography}

Bosch DJ (1991) Transforming Mission, Paradigm Shifts in Theology of Mission. Maryknoll, New York: Orbis Books.

Ende MVD (1990) Imre Lajos élete és teológiai munkássága (The Life and Theological Work of Lajos Imre) PhD Paper in Theology, presented at Egyetemi Fokú Egységes Protestáns Teológiai Intézet, Kolozsvár/Cluj-Napoca, 1982. Budapest: Ráday College Press.

Imre L (1915) Az Út (1915-16). Kolozsvár.

Imre L (1930) Egyházunk és a misszió (Our Church and Mission). In Mi a külmisszió (What Is Foreign Missions?) The Senior Class of the Young [Men's] Christian Association (eds) Cluj-Kolozsvár: Ifjú Erdély Kiadása.

Imre L (1999) Önéletirása (Autobiography). Cluj/Kolozsvár: Erdélyi Református Egyháztörténeti Füzetek 2.

Kenessey B (1909) Püspöki évi jelentés (Annual Report of the Bishop to the General Assembly). In Református Szemle.

Kovács Á (2010) Hitvédelem és egyháziasság. A debreceni új orthodoxia vitája a liberális teológiával (Apologetics and Church Centeredness. The debate of Debrecen New Orthodoxy with Liberal Theology) Budapest: L'Harmattan.

Kovács Á (2014) Die Antwort der Debrecener neuen Orthodoxie auf den theologischen Liberalismus im neunzehnten Jahrhundert in Ungarn. Zeitshrift für Neuere Theologiegeschichte 21(1): 51-71.

Kool AK (1995) God Moves in Mysterious Ways. The Hungarian Protestant Foreign Mission Movement 1796-1951 Zoetermeer: Boekcentrum.

Molnár J (1996) Kecskeméthy István, 1864-1938. In Akik jó bizonyságot nyertek, A Kolozsvári Református Teológia tanárai 1895-1948 (Those Who Have Gained a Good Testimony: the Professors of the Kolozsvár Reformed Theological Seminary 1895-1948). Kolozsvár.

Nagy L (1978) Kecskeméthy István tanulóévei (The Academic Life of István Kecskeméthy). Református Szemle.

Oliver R (1991) The Reformation in Eastern Europe; Progress and Decline. In Advancing in Adversity, Papers read at the 1991 Westminster Conference. Westminster Conference.

Ravasz L (1992) Emlékezéseim ('My Memoirs'). Budapest: Református Egyház Zsinati Irodájának Sajtóosztálya.

Ravasz L (1909) Mott János (John Mott). Református Szemle.

Tavaszy S (1929) Az egyház református dogmatikai felfogása (The Reformed Dogmatic Concept of Church). In A Kijelentés feltétele alatt, Theologiai értekezések (Under the Condition of Revelation, Theological Studies) Dolgozatok a református theologiai tudományok köréből. Cluj-Kolozsvár: Erdélyi Református Egyházkerület kolozsvári theol. Fakultásának tanárai, Nr. 2. 